\title{
Entomogen galls in a Seasonal Semideciduous Forest area in Sorocaba, Southeast of São Paulo State, Brazil
}

\author{
Leticia Salvioni Ansaloni ${ }^{1}$, Julia Rodrigues Salmazo ${ }^{1}$ \& Maria Virginia Urso Guimarães ${ }^{1 * \mathbb{C}}$ \\ ${ }^{1}$ Universidade Federal de São Carlos, Sorocaba, SP, Brasil \\ *Corresponding author: Maria Virginia Urso Guimarães, e-mail: mvirginiaurso@gmail.com
}

\begin{abstract}
ANSALONI, L. S., SALMAZO, J. R., URSO-GUIMARÃES, M.V. Entomogen galls in a Seasonal Semideciduous Forest area in Sorocaba, Southeast of São Paulo State, Brazil. Biota Neotropica. 18(4): e20180523. http://dx.doi.org/10.1590/1676-0611-BN-2018-0523
\end{abstract}

\begin{abstract}
In this paper we studied the occurrence of insect galls and gall makers in a Seasonal Semideciduous Forest area in Sorocaba Municipality, Southeast of São Paulo State, Brazil. One hundred and thirteen morphotypes of galls on 54 species of host plants of 24 different families were found. The families of host plants richer in gall morphotypes were Fabaceae $(\mathrm{N}=26)$ and Malpighiaceae $(\mathrm{N}=19)$; the super host plants species were Copaifera langsdorffi Desf. (Fabaceae) $(\mathrm{N}=16)$, Stigmaphyllon lalandianum (Aubl.) Marchand (Malpighiaceae) $(\mathrm{N}=11)$, Protium heptaphyllum A. Juss. (Burseraceae) $(\mathrm{N}=10)$, Serjania lethalis A.St.-Hil. (Sapindaceae) $(\mathrm{N}=5)$. Most of the galls were found empty, but insects of the family Cecidomyiidae (Diptera) were responsible for the induction of $92 \%(\mathrm{~N}=11)$ of the galls and Hymenoptera $(\mathrm{N}=1)$ for $8 \%$. We registered insects of the order Hymenoptera $(\mathrm{N}=11)$ as parasitoids and as successors Hemiptera $(\mathrm{N}=8)$, Acari $(\mathrm{N}=7)$, Psocoptera $(\mathrm{N}=4)$, Hymenoptera (Formicidae, $\mathrm{N}=2$ ), Collembola and Thysanoptera $(\mathrm{N}=1$ each). Two species of Cecidomyiidae with inquiline habit were also obtained, Neolasioptera sp. and Trotteria sp. Five plant species were registered as hosts for cecidomyiids for the first time: Aloysia virgata (Ruiz \& Pav.) Juss., Calliandra foliolosa Benth., Myrcia splendens (Sw.) DC., Serjania lethalis A.St.-Hil., and Tapirira guianiensis Aubl. This is the first study of gall characterization, gall makers and associated fauna of the Southeast of the State of São Paulo.
\end{abstract}

Keywords: Atlantic Forest Biome, biodiversity, gall makers, Neotropical region, plant-insect interaction.

\section{Galhas entomógenas em uma área de Mata Estacional Semidecidual em Sorocaba, Sudeste do Estado de São Paulo, Brasil}

Resumo: Neste trabalho, estudamos a ocorrência de galhas entomógenas e insetos galhadores em uma área de Mata Estacional Semidecidual em Sorocaba, Sudeste do Estado de São Paulo, Brasil. Cento e treze morfotipos de galhas em 54 espécies de plantas hospedeiras de 24 famílias distintas foram encontradas. As famílias de plantas hospedeiras mais ricas em morfotipos de galhas foram Fabaceae $(\mathrm{N}=26)$ e Malpighiaceae $(\mathrm{N}=19)$ e as espécies de plantas super hospedeiras foram Copaifera langsdorffi Desf. (Fabaceae) $(\mathrm{N}=16)$, Stigmaphyllon lalandianum (Aubl.) Marchand (Malpighiaceae) $(\mathrm{N}=11)$, Protium heptaphyllum A. Juss. (Burseraceae) $(\mathrm{N}=10)$, Serjania lethalis A.St.-Hil. (Sapindaceae) $(\mathrm{N}=5)$. A maioria das galhas foi encontrada vazia, mas insetos da família Cecidomyiidae (Diptera) foram responsáveis pela indução de $92 \%(\mathrm{~N}=11)$ das galhas e Hymenoptera $(\mathrm{N}=1)$ por $8 \%$. Nós registramos insetos da Ordem Hymenoptera $(\mathrm{N}=11)$ como parasitoides e Hemiptera $(\mathrm{N}=8)$, Acari $(\mathrm{N}=7)$, Psocoptera $(\mathrm{N}=4)$, Hymenoptera (Formicidae, $\mathrm{N}=2)$, Collembola e Thysanoptera $(\mathrm{N}=1$ cada) como successores. Duas espécies de Cecidomyiidae com hábito inquilino também foram obtidas, Neolasioptera sp. e Trotteria sp. Cinco espécies de plantas foram registradas como hospedeiras para cecidomiídeos pela primeira vez: Aloysia virgata (Ruiz \& Pav.) Juss., Calliandra foliolosa Benth., Myrcia splendens (Sw.) DC., Serjania lethalis A.St.-Hil. e Tapirira guianiensis Aubl. Este é o primeiro estudo de caracterização de galhas entomógenas, galhadores e fauna do Sudeste do Estado de São Paulo.

Palavras-chave: Bioma Mata Atlântica, biodiversidade, galhador, região Neotropical, interação ineto-planta. 


\section{Introduction}

Studies on the occurrence and characterization of galls in Brazil have increased significantly in the last 30 years, especially in Cerrado Biome (Fernandes et al. 1988, Fernandes et al. 1997, Urso-Guimarães et al. 2003, Maia \& Fernandes 2004, Scareli-Santos et al. 2005, Urso-Guimarães \& Scareli-Santos 2006, Maia et al. 2008, Saito \& Urso-Guimarães 2012, Carneiro et al. 2009, Coelho et al. 2009, Malves \& Frieiro-Costa 2012, Maia 2012, Araújo et al. 2013, Bergamini et al. 2017), Restinga and Ombrophilous Forest from Atlantic Forest Biome (Maia et al. 2008, Bregonci et al. 2010, Maia 2013a, Maia 2013b, Rodrigues et al. 2014, Maia et al. 2014, Maia \& Carvalho-Fernandes 2016).

However, environments such as Pantanal (Julião et al. 2002, Urso-Guimarães et al. 2017), Caatinga (Carvalho-Fernandes et al. 2012, Santos et al. 2011), Amazonic Forest (Julião et al. 2015) and Seasonal Semideciduous Forest of Atlantic Forest Biome (Santos et al. 2010, Carvalho et al. 2015) are considered little sampled and their biodiversity is still poorly understood. Particularly, the Seasonal Semideciduous Forest is considered priority area for conservation in Atlantic Forest Biome due to two factors: the biological richness and the fast degradation in recent years to economic activities in the Southeast region of Brazil (Martins et al. 2003).

Considering that gall morphotypes are used as a surrogate for species of gall-inducing insects because of the host-specificity of insect and host plant species (Carneiro et al. 2009, Bergamini et al. 2017), we described in this study the gall morphotypes with the register of the association between gall maker and their host plant species in a Seasonal Semideciduous Forest area in Sorocaba Municipality, the first survey to the Southeast region of São Paulo State, Brazil.

\section{Material and Methods}

\section{Study area}

The Seasonal Semideciduous Forest fragment of the sampling area is located on the campus of the Universidade Federal de São Carlos (UFSCar), located in the municipality of Sorocaba ( $47^{\circ} 31$ ' $28^{\circ}$ "W and $23^{\circ} 34^{\prime} 53^{\prime}$ 'S), Southeast region of São Paulo State, $580 \mathrm{~m}$ altitude and climate Cwa-Köppen classification. This area is located in the transition between the Planalto Atlântico and the São Paulo State Peripheral Depression. Among forest remnants, Cerrado elements are found in the flatter areas and Seasonal Semideciduous Forest in the areas closest to water bodies or slopes (Corrêa et al. 2014). The Sorocaba campus of UFSCar is $700,000 \mathrm{~m}^{2}$ in size and has a vegetative mosaic composed by two typical phytophysiognomies of the region, the Seasonal Semideciduous Forest and the Cerrado, remaining of continuous forest before its exploration for economic activities (Fig. 1).

\section{Sampling}

The samplings of this study were carried out between the years 2014 to 2016, with seasonal frequency (trimonthly), in twelve samplings of four hour each, totalizing 48 hours of sampling effort. Branches of the host plants with galls were collected, pictured and placed for rearing in labeled plastic pots to obtain the adults of the associated fauna. All individuals obtained were preserved in $80 \%$ alcohol.

\section{Treatment of the samples}

The gall midges were mounted later on microscope slides following Gagné (1994) methodology. The cecidomyiids were identified using keys of Gagné (1994). Other arthropods and host plant species were sent to specialists for identification. The gall morphotypes were characterized according Isaías et al. (2013). The specimens of the associated fauna are deposited in the Laboratório de Sistemática de Diptera/UFSCar and the exsiccates of host plants with reproductive material will be deposited in Herbário UFSCar Sorocaba (SORO).

\section{Results and Discussion}

A total of 113 gall morphotypes were found in 54 species of 24 host family families in the remnants of Seasonal Semideciduous Forest in the Southeast of São Paulo State. The average of gall morphotypes per plant species is 2.1, a high average when compared with other areas with the same phytophysiognomy (Table 1) and comparable to dry environments (see Urso-Guimarães et al. 2017 for detailed discussion). The morphotypes are characterized in Table 2 and are presented in Figures 2 to 6 .

The morphotypes were obtained most frequently in leaves (70\%) followed by stems (30\%), flower bud (2\%), tendril and fruit (1\%). Three morphotypes occurred in more than one vegetal organ; the fusiform morphotypes on leaf and stem of Protium heptaphyllum, the globoid morphotype on leaf vein and stem of Copaifera langsdorffii, and the amorphous morphotype on flower and fruit of Eugenia pluriflora. Our results are slightly lower than other surveys conducted in different environments (Maia, 2001, Urso-Guimarães et al. 2003, Fernandes \& Negreiros, 2006 Maia et al. 2008, Saito \& Urso-Guimarães 2012, Maia \& Carvalho-Fernandes 2016, Bergamini et al. 2017, Urso-Guimarães et al. 2017) where the percentage of leaf galls ranges from 75 to $90 \%$. The shape of galls more frequent was globoid (42\%) followed by lenticular (26\%), fusiform (18\%), conical (7\%), cylindrical (3\%), amorphous, concave and marginal roll (2\% each), and linear $(1 \%)$. The color more frequently sampled in galls were green (42\%) and brown (27\%), followed by cream $(10 \%)$, red and yellow ( $3 \%$ each) with other colors appearing in less than $1 \%$. Frequently there are changes of color along the development of gall and as observed in the most galls, it passes from green to brown. In Campomanesia sp., Eugenia pluriflora, Copaifera langsdorffii, Moquiniastrum polymorphum, and Serjania lethalis it was observed changing in three different colors during maturation process. Lithraea molleoides presented the largest color variation found on galls in this study: four different colors - pink, red, green, and brown. In relation to the pubescence and internal chambers, most galls were glabrous (94\%) and unilocular (100\%) (for detailed discussion about presence/absence of trichomae, see Saito \& Urso-Guimarães, 2012). In the Table 2 are presented a detailed morphological description of the collected galls.

In a decreasing order of occurrence of galls morphotypes appear the Fabaceae $(\mathrm{N}=26)$, followed by Malpighiaceae $(\mathrm{N}=19)$, Myrtaceae $(\mathrm{N}=11)$, Burseraceae $(\mathrm{N}=10)$, Asteraceae $(\mathrm{N}=7)$, Anacardiaceae and Sapindaceae $(\mathrm{N}=5$ each $)$.

Information about richness of morphotypes of other families and species is given in Table 3. This study corroborates others in the Neotropical region that indicates the richest families as the 

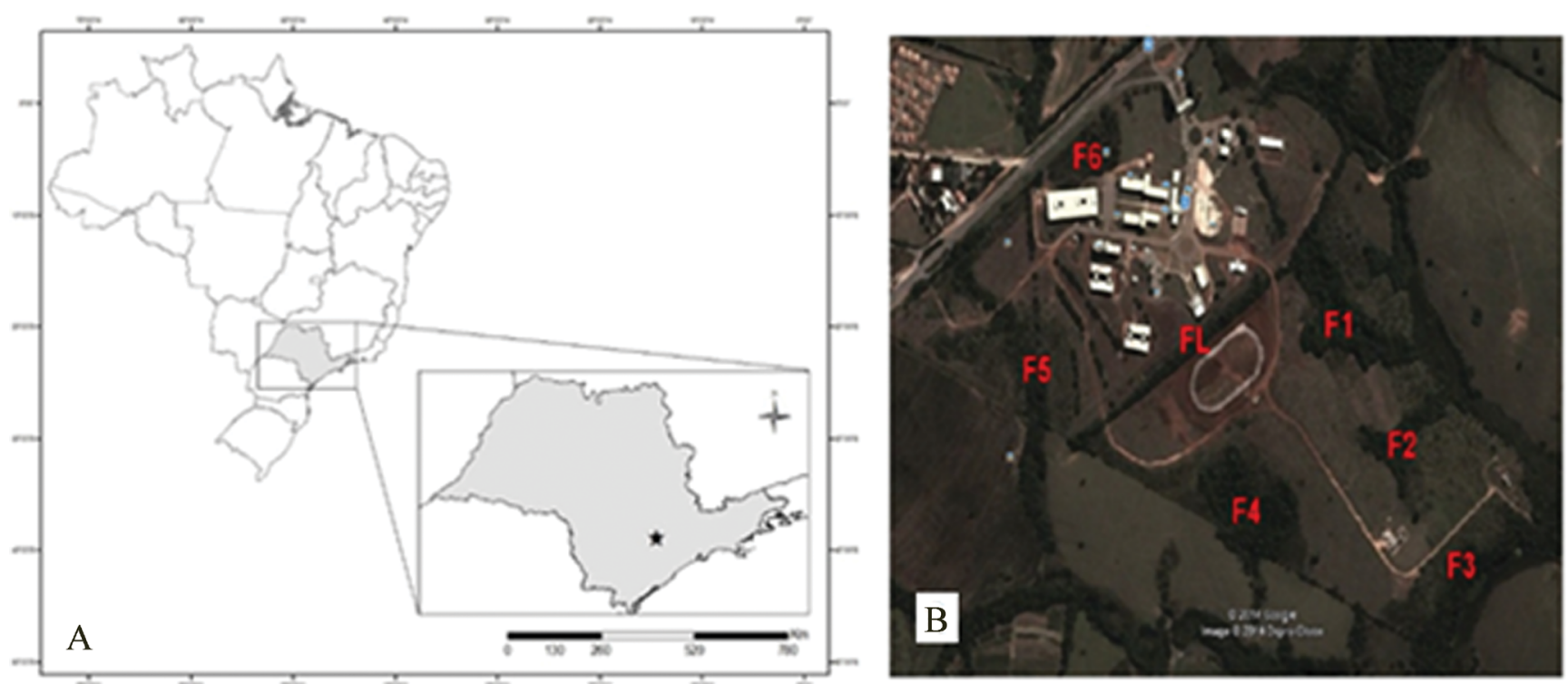

Figure 1. A. Localization of the Sorocaba Municipality in Southeast of São Paulo State; B. Aerial view of the Sorocaba campus of Universidade de São Carlos, Southeast of São Paulo State, Brazil, with reference of the fragments of the area sampled (FL, F1, F2, F3, F4, F5, F6). (Source: Google Earth, 2017).

Table 1. Richness of gall morphotypes in localities with Seasonal Semideciduous Forest phytophysiognomy.

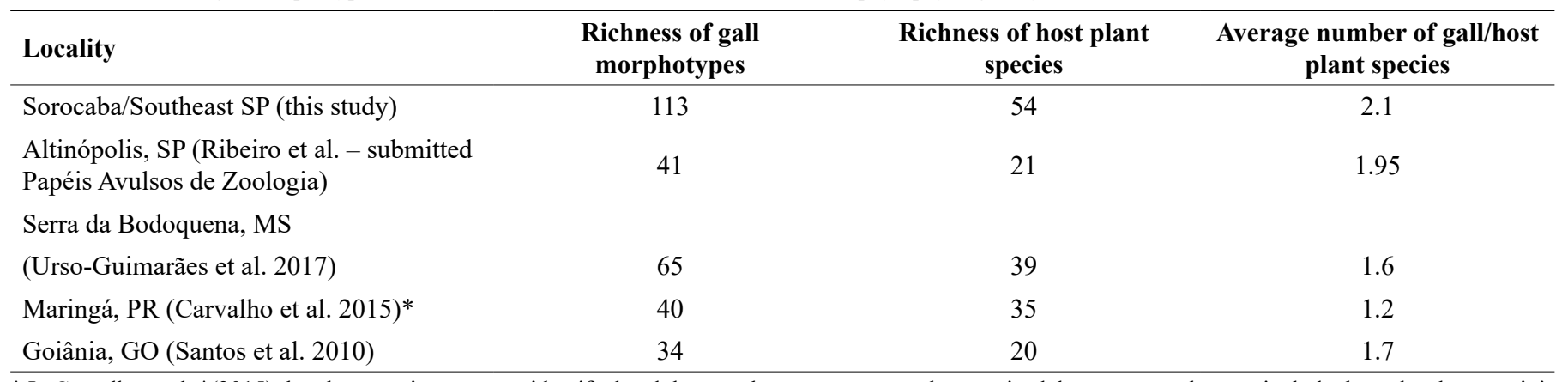

* In Carvalho et al. *(2015) the plant species were not identified and the morphotypes were not characterized, however we chose to include these data because it is one of the few works in the area of Seasonal Semideciduous Forest phytophysiognomy.

richer in number of gall morphotypes (Gagné 1994, Araújo 2011, Santana \& Isaias 2014). It's important to highlight the high number of morphotypes found in the same plant species (the super host plants sensu Veldtman \& McGeoch 2003). The presence of super hosts increase the counting of morphotypes per family in the studied area, as related by Araújo (2011) to Goiânia (GO, Brazil) and Ribeiro et al. (submitted Papéis Avulsos de Zoologia) to Altinópolis (SP, Brazil). The presence of Copaifera langsdorffii with 16 morphotypes, Stigmaphyllon lalandianum with 11, Protium heptaphyllum with 10, and Serjania lethalis with five morphotypes in this study are examples of it. Protium heptaphyllum was referred before as super host in Maia \& Fernandes (2004) and Copaifera langsdorffii in Oliveira et al. (2008), Fernandes et al. (1988) and Drummond et al. (2008), both from cerrado areas in Minas Gerais State.

Most of the galls were found empty. Although only $12 \%$ of gall makers were obtained (Table 4), insects of the family Cecidomyiidae (Diptera) were responsible for the induction of $92 \%$ of galls $(\mathrm{N}=11)$ and the order Hymenoptera $(\mathrm{N}=1)$ for $8 \%$. The other insects associated with galls $(30 \%, \mathrm{~N}=34)$ were considered parasitoids, successors or inquilines. As parasitoids were registered insects of the order Hymenoptera $(\mathrm{N}=11)$ and as successors, the orders Hemiptera $(\mathrm{N}=8)$,
Acari $(\mathrm{N}=7$, Iphiseiodes zuluagai Denmark \& Muma, Iphiseiodes saopaulus Denmark \& Muma), Psocoptera $(\mathrm{N}=4)$, Hymenoptera (Formicidae, $\mathrm{N}=2$ ), Collembola and Thysanoptera $(\mathrm{N}=1$ each). Two species of Cecidomyiidae with inquiline habit were also obtained, Neolasioptera sp. and Trotteria sp.

This is the first survey of the association of gall, gall makers, host plants and associated fauna in Seasonal Semidecidual Forest to the Southeast of the State of São Paulo. In addition to the associations, five plant species were registered as hosts for cecidomyiids for the first time: Aloysia virgata, Calliandra foliolosa, Myrcia splendens, Serjania lethalis and Tapirira guianiensis. In the Southeast of the State of São Paulo there are several areas preserved in Conservation Units (UC), but the majority is dedicated to the protection of Dense Ombrophylous Forest vegetation. Few fragments of Seasonal Semideciduous Forest are included in that Conservation Units. Studies like this are still essential for the registration of host plants that may be at risk of extinction as well as the entire trophic network dependent on them in Seasonal Semideciduous Forest environments, a priority area for conservation in Atlantic Forest Biome, due to the biological richness and the fast degradation in recent years to economic activities in the Southeast region of Brazil, as stated to Martins et al. (2003). 
Ansaloni, L.S. et al.

Table 2. Characterization of insect galls recorded in Sorocaba, Southeast of São Paulo State, Brazil by host plant. "Figure" refers to gall morphotype's picture, and "." refers to no pictured morphotypes.

\begin{tabular}{|c|c|c|c|c|c|c|}
\hline $\begin{array}{l}\text { Host plant } \\
\text { family }\end{array}$ & Host plant species & Organ & Shape & Color & Pube-scence & Figure \\
\hline \multirow[t]{5}{*}{ Anacardiaceae } & Lithraea molleoides (Vell.) Engl. & Leaf & Globoid & Pink/Red/Green/Brown & No & $2 \mathrm{~A}$ \\
\hline & Lithraea molleoides & Stem & Globoid & Brown & No & $2 \mathrm{~B}$ \\
\hline & Tapirira guianensis Aubl. & Stem & Globoid & Cream & No & $2 \mathrm{C}$ \\
\hline & Tapirira guianensis & Leaf & Lenticular & Green & No & $2 \mathrm{D}$ \\
\hline & Schinus terebinthifolia Raddi & Leaf & $\begin{array}{l}\text { Marginal } \\
\text { roll }\end{array}$ & Red & No & $2 \mathrm{E}$ \\
\hline \multirow[t]{2}{*}{ Annonaceae } & Annona dioica A.St.-Hil. & Leaf & Globoid & Cream & No & $2 \mathrm{~F}$ \\
\hline & Duguetia furfuracea (A.St.-Hil.) Saff. & Leaf & Globoid & Green & Yes & $2 \mathrm{G}$ \\
\hline \multirow[t]{2}{*}{ Apocynaceae } & Oxypetalum banksii R.Br. ex Schult. & Leaf & Lenticular & Green/Brown & No & $2 \mathrm{H}$ \\
\hline & Condylocarpon sp. & Stem & Globoid & Cream & No & 2I \\
\hline \multirow{4}{*}{ Asteraceae } & Mikania sp. & Leaf & Globoid & Green & No & $2 \mathrm{M}$ \\
\hline & Mikania sp. & Leaf & Lenticular & Green & No & $2 \mathrm{~N}$ \\
\hline & $\begin{array}{l}\text { Moquiniastrum polymorphum (Less.) } \\
\text { G. Sancho }\end{array}$ & Leaf & Lenticular & Green/Yellowish/Brown & No & $2 \mathrm{O}$ \\
\hline & Moquiniastrum polymorphum & Stem & Fusiform & Green/Brown & No & $2 \mathrm{P}$ \\
\hline Bignoniaceae & Bignoniaceae sp. & Leaf & Lenticular & White & No & $2 \mathrm{Q}$ \\
\hline \multirow[t]{5}{*}{ Burseraceae } & $\begin{array}{l}\text { Protium heptaphyllum (Aubl.) } \\
\text { Marchand }\end{array}$ & Leaf & Conical & Brown & Yes & $2 \mathrm{R}$ \\
\hline & Protium heptaphyllum & Leaf & Lenticular & Brown & No & $2 \mathrm{~S}$ \\
\hline & Protium heptaphyllum & Stem & Globoid & Brown & No & - \\
\hline & Protium heptaphyllum & Stem & Fusiform & Brown & No & $3 \mathrm{E}$ \\
\hline & Protium heptaphyllum & Leaf/Stem & Fusiform & Green/Brown & No & $3 \mathrm{~F}$ \\
\hline \multirow[t]{3}{*}{ Cannabaceae } & Celtis iguanaea (Jacq.) Sarg. & Leaf & Conical & Green & No & $3 \mathrm{G}$ \\
\hline & Celtis iguanaea & Stem & Fusiform & Brown & No & $3 \mathrm{H}$ \\
\hline & Celtis iguanaea & Leaf & Globoid & Green & No & $3 \mathrm{I}$ \\
\hline Caryocaraceae & Caryocar brasiliense Cambess. & Leaf & Globoid & Green & No & $3 \mathrm{~J}$ \\
\hline Celastraceae & Hippocratea volubilis L. & Leaf & Lenticular & Brown & Yes & $3 \mathrm{~K}$ \\
\hline Convolvulaceae & Ipomoea sp. & Stem & Globoid & Cream & No & $3 \mathrm{~L}$ \\
\hline \multirow[t]{6}{*}{ Fabaceae } & Andira humilis Mart. ex Benth. & Leaf & Globoid & Green & No & $3 \mathrm{M}$ \\
\hline & Bauhinia sp. & Leaf & Fusiform & Green & No & - \\
\hline & Bauhinia forficata Link & Stem & Fusiform & Brown & No & $3 \mathrm{~N}$ \\
\hline & Bauhinia holophylla (Bong.) Steud. & Leaf & Globoid & Green & No & $3 \mathrm{O}$ \\
\hline & Bauhinia holophylla & Stem & Fusiform & Green & No & $3 \mathrm{P}$ \\
\hline & Bauhinia longifolia (Bong.) Steud. & Leaf & Globoid & Green & No & $3 Q$ \\
\hline
\end{tabular}


Entomogen galls in Sorocaba, SP, Brazil

Continued Table 1.

\begin{tabular}{|c|c|c|c|c|c|c|}
\hline $\begin{array}{l}\text { Host plant } \\
\text { family }\end{array}$ & Host plant species & Organ & Shape & Color & Pube-scence & Figure \\
\hline & Bauhinia longifolia & Stem & Fusiform & Brown & No & $3 \mathrm{R}$ \\
\hline & Calliandra foliolosa Benth. & Stem & Globoid & Brown & No & $3 \mathrm{~S}$ \\
\hline & Calliandra foliolosa & Stem & Fusiform & Brown & No & $3 \mathrm{~T}$ \\
\hline & Copaifera langsdorffii Desf. & Leaf & Lenticular & Green/Yellowish/Brown & No & $4 \mathrm{~A}$ \\
\hline & Copaifera langsdorffii & Leaf & Globoid & White/Pink & No & - \\
\hline & Copaifera langsdorffii & Leaf & Globoid & Black & No & $4 \mathrm{C}$ \\
\hline & Copaifera langsdorffii & Leaf & Globoid & Green & No & - \\
\hline & Copaifera langsdorffii & Leaf & Globoid & Green/Brown & No & - \\
\hline & Copaifera langsdorffii & Stem & Fusiform & Cream & No & - \\
\hline & Copaifera langsdorffii & Stem & Globoid & Green & No & - \\
\hline & Copaifera langsdorffii & Stem & Globoid & Green & No & - \\
\hline & Copaifera langsdorffii & Stem & Globoid & Brown & No & - \\
\hline & Copaifera langsdorffii & Stem & Globoid & Cream & No & $4 \mathrm{E}$ \\
\hline & Copaifera langsdorffii & Stem & Globoid & Brown & No & $4 \mathrm{~F}$ \\
\hline & Inga edulis Mart. & Flower & Amorphous & Green & No & $4 \mathrm{G}$ \\
\hline Lauraceae & Nectandra grandiflora Ness & Stem & Globoid & Cream & No & $4 \mathrm{H}$ \\
\hline \multirow{14}{*}{ Malpighiaceae } & Byrsonima intermedia A.Juss. & Leaf & Lenticular & Brown & No & $4 \mathrm{~N}$ \\
\hline & Byrsonima intermedia & Stem & Globoid & Cream & No & 40 \\
\hline & $\begin{array}{l}\text { Janusia guaranitica (A.St.-Hil.) } \\
\text { A.Juss. }\end{array}$ & Leaf & Globoid & Green & Yes & $4 \mathrm{P}$ \\
\hline & Janusia guaranitica & Stem & Fusiform & Brown & No & $4 \mathrm{Q}$ \\
\hline & $\begin{array}{l}\text { Niedenzuella multiglandulosa (A.Juss.) } \\
\text { W.R.Anderson }\end{array}$ & Leaf & Lenticular & Green & No & - \\
\hline & Stigmaphyllon lalandianum A.Juss. & Leaf & Fusiform & Brown & No & $4 \mathrm{R}$ \\
\hline & Stigmaphyllon lalandianum & Leaf & Conical & Green & No & - \\
\hline & Stigmaphyllon lalandianum & Leaf & Conical & Green & No & - \\
\hline & Stigmaphyllon lalandianum & Leaf & Concave & Green & No & $4 \mathrm{~S}$ \\
\hline & Stigmaphyllon lalandianum & Leaf & Lenticular & Green & No & $4 \mathrm{~T}$ \\
\hline & Stigmaphyllon lalandianum & Leaf & Lenticular & Green & No & - \\
\hline & Stigmaphyllon lalandianum & Leaf & Lenticular & Yellowish & No & - \\
\hline & Stigmaphyllon lalandianum & Stem & Fusiform & Cream & No & - \\
\hline & Stigmaphyllon lalandianum & Stem & Fusiform & Red & No & - \\
\hline
\end{tabular}


Ansaloni, L.S. et al.

Continued Table 1.

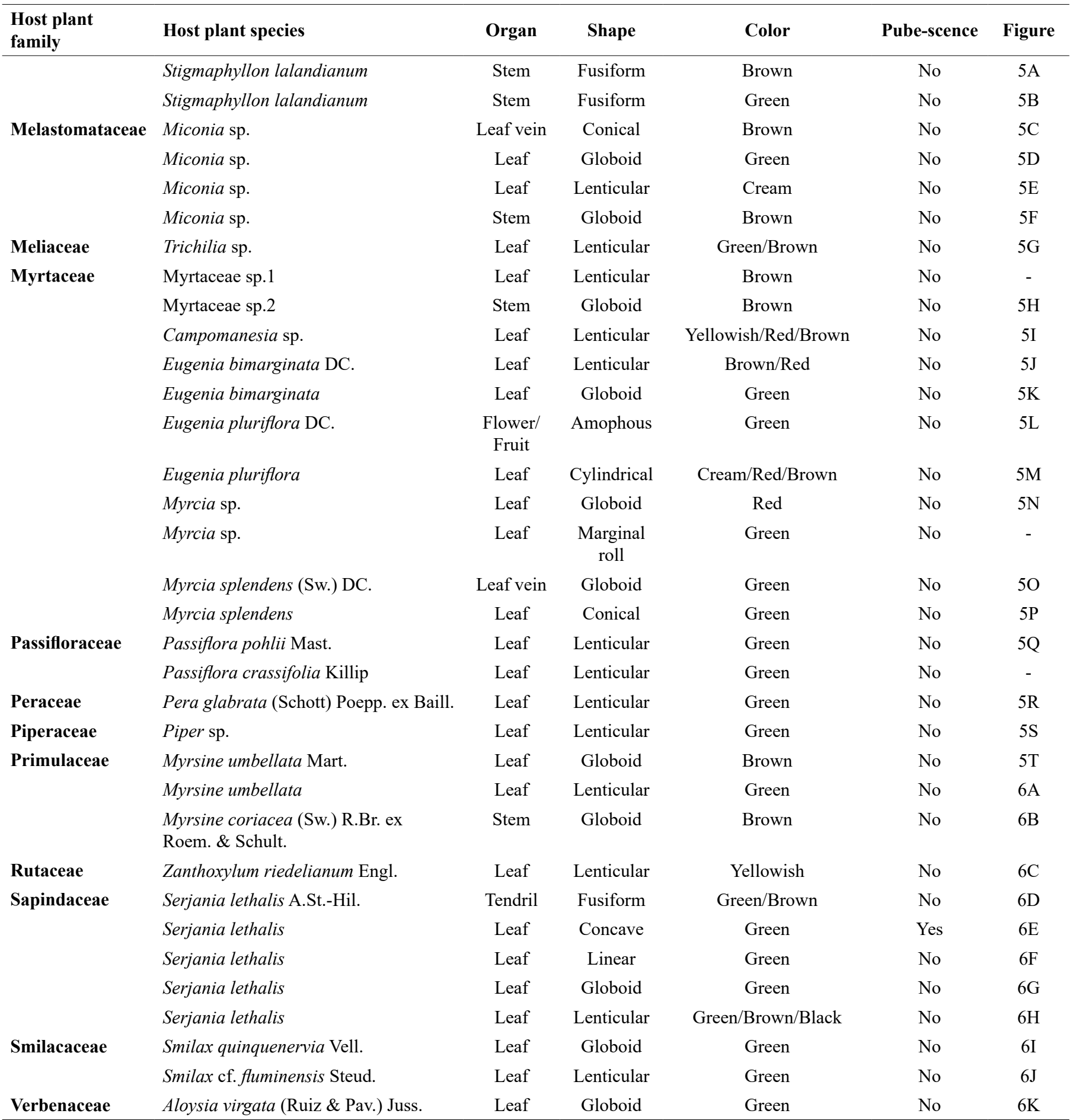



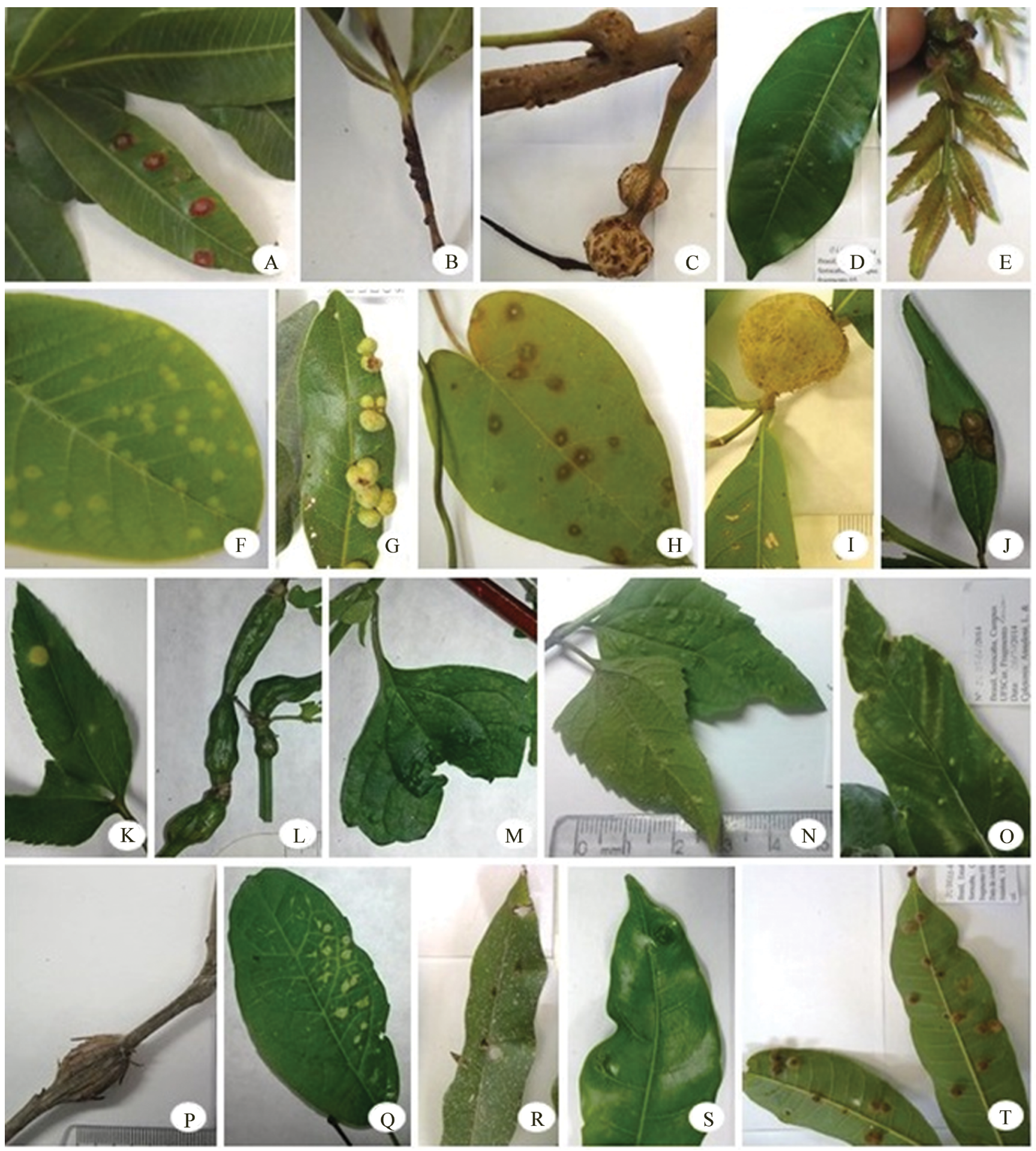

Figure 2. Gall morphotypes of Sorocaba, Southeast of São Paulo State, Brazil by host plant. Anacardiaceae: A-B. Lithraea molleoides, C-D. Tapirira guianiensis, E. Schinus terebinthifolius. Annonaceae: F. Annona dioica, G. Duguetia furfuracea. Apocynaceae: H. Oxypetalum banksii, I. Condylocarpon sp. Asteraceae: J. Chromolaena laevigata, K. Bidens segetum, L. Calea pinnatifida, M-N. Mikania sp., O-P. Moquiniastrum polymorphum. Bignoniaceae: Q. Bignoniaceae sp. Burseraceae: R-T. Protium heptaphyllum. (Pictures: Ansaloni, L. S. and Salmazo, J. R.). 


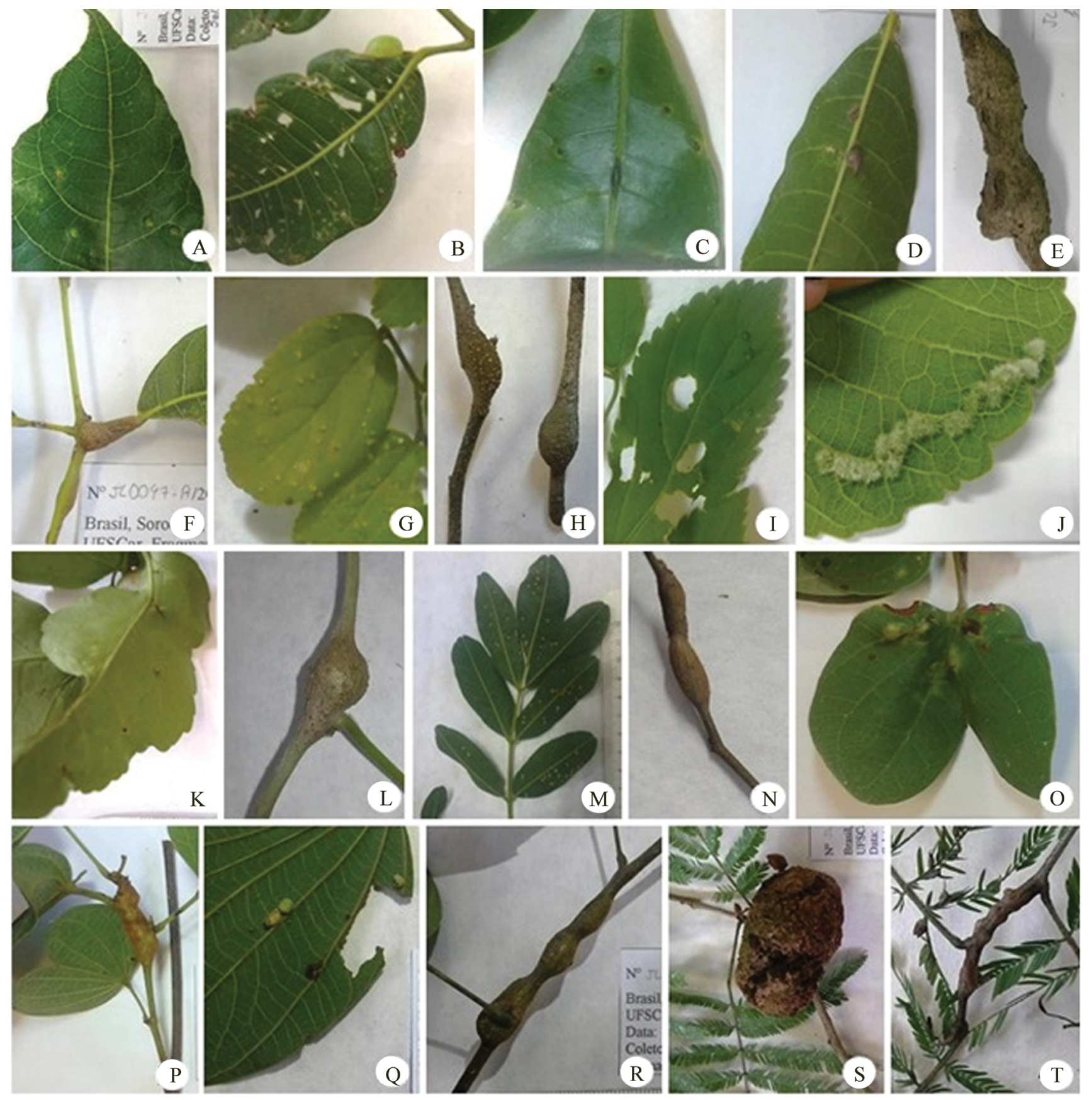

Figure 3. Gall morphotypes of Sorocaba, Southeast of São Paulo State, Brazil by host plant. Burseraceae: A-F. Protium heptaphyllum. Cannabaceae: G-I. Celtis iguanaea. Caryocaraceae: J. Caryocar brasiliense. Celastraceae: K. Hippocratea volubilis, L. Ipomoea sp. Fabaceae: M. Andira humilis, N. Bauhinia forficata, O-P. Bauhinia holophylla, Q-R. Bauhinia longifolia, S-T. Calliandra foliosa. (Pictures: Ansaloni, L. S. and Salmazo, J. R.). 
Entomogen galls in Sorocaba, SP, Brazil
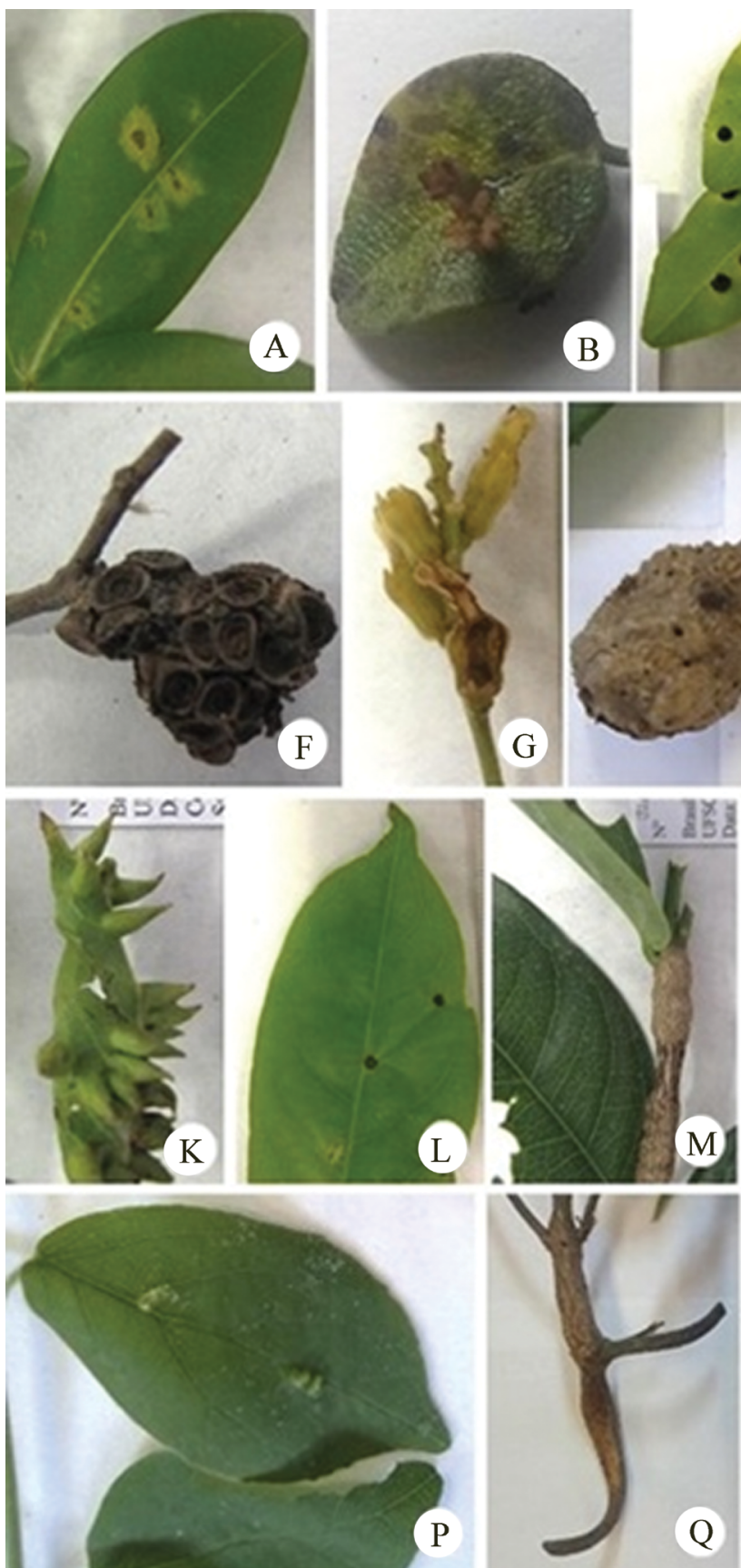

B

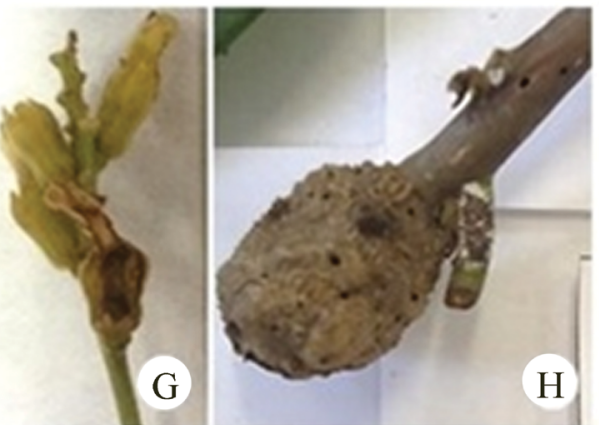

C)
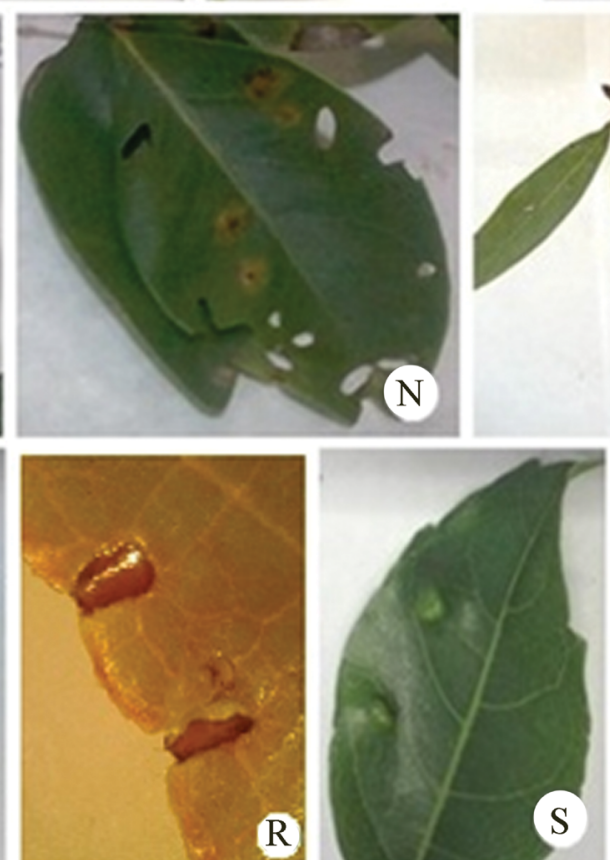

$\mathrm{S}$

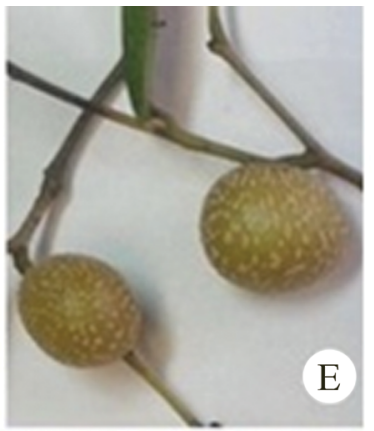

E
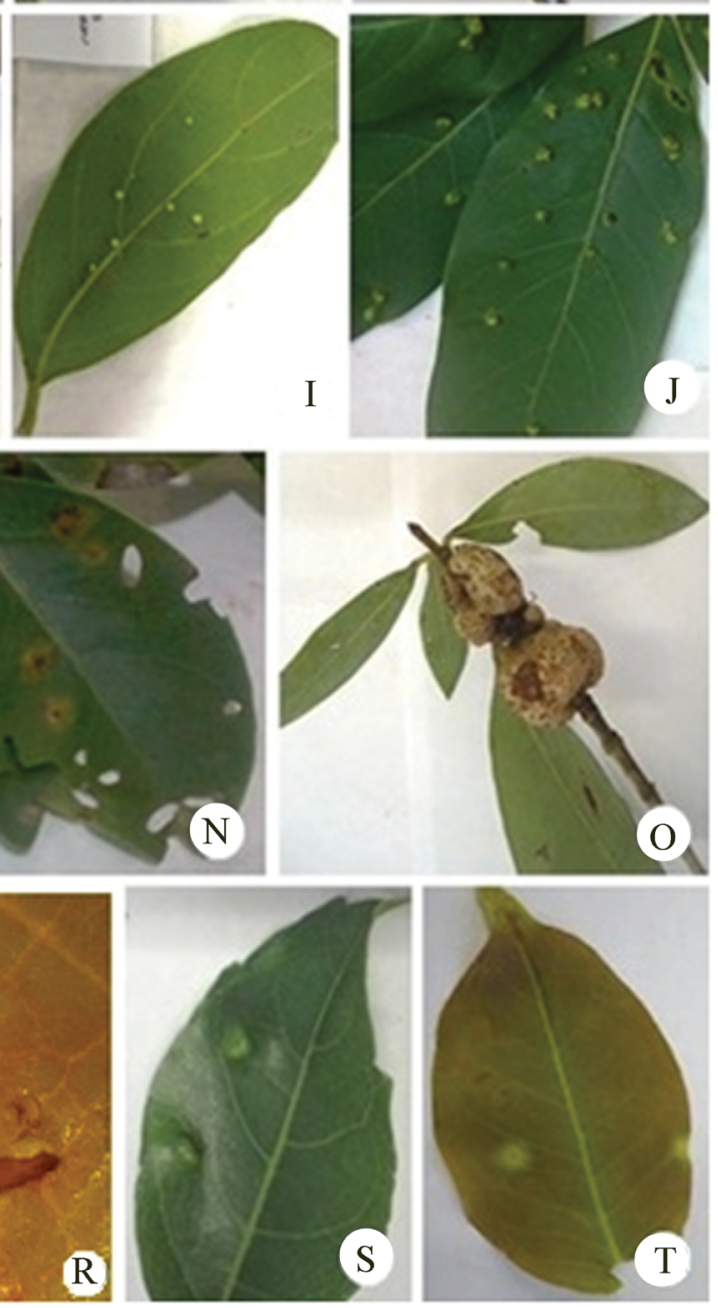

Figure 4. Gall morphotypes of Sorocaba, Southeast of São Paulo State, Brazil by host plant. Fabaceae: A-F. Copaifera langsdorffii. G. Inga edulis. Lauraceae: H. Nectandra grandiflora, I. Persea sp., J. Persea willdenovii. Malpighiaceae: K-M. Diplopterys pubipetala, N-O. Byrsonima intermedia, P-Q. Janusia guaranitica, R-T. Stigmaphyllon lalandianum. (Pictures: Ansaloni, L. S. and Salmazo, J. R.). 

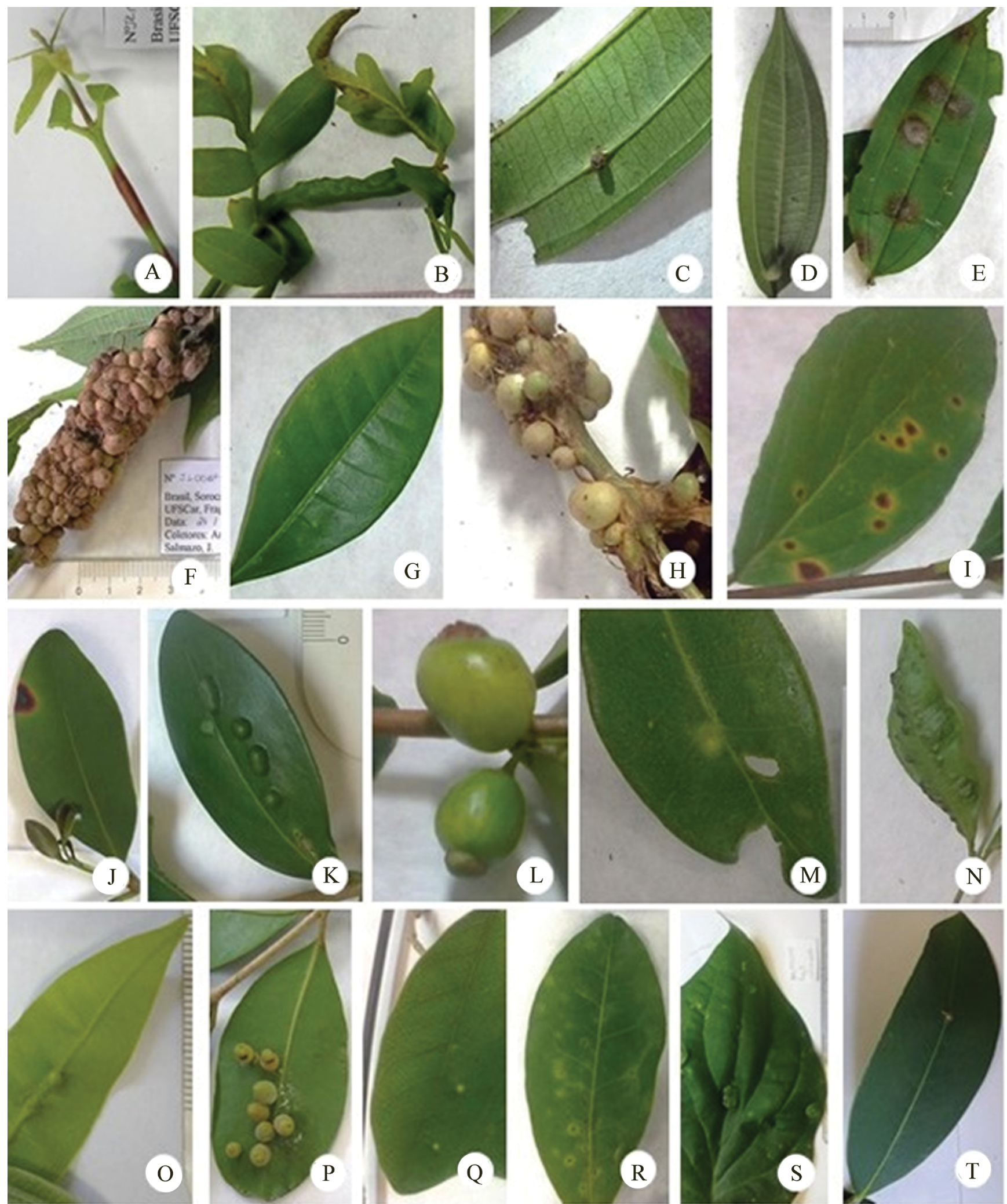

Figure 5. Gall morphotypes of Sorocaba, Southeast of São Paulo State, Brazil by host plant. Malpighiaceae: A-B. Stigmaphyllon lalandianum. Melastomataceae: C-F. Miconia sp. Meliaceae: G. Trichilia sp. Myrtaceae: H. Myrtaceae sp. 2, I. Campomanesia sp., J-K. Eugenia bimaginata, L-M. Eugenia pluriflora, N. Myrcia sp., O-P. Myrcia splendens. Passifloraceae: Q. Passiflora pohlii. Peraceae: R. Pera glabrata. Piperaceae; S. Piper sp. Primulaceae: T. Myrsine umbellata (Pictures: Ansaloni, L. S. and Salmazo, J. R.). 
Entomogen galls in Sorocaba, SP, Brazil

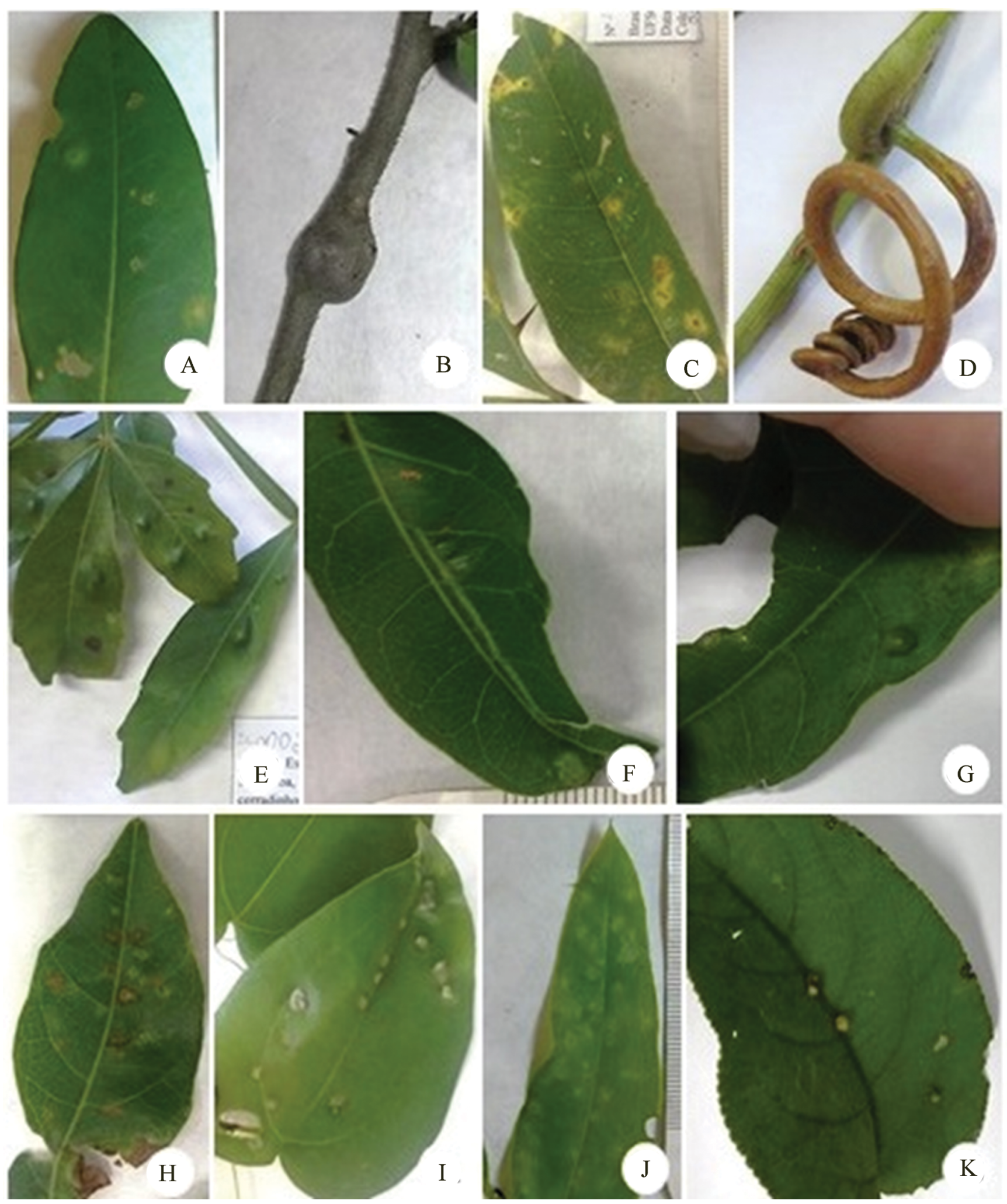

Figure 6. Gall morphotypes of Sorocaba, Southeast of São Paulo State, Brazil by host plant. Primulaceae: A. Myrsine umbellata, B. Myrsine coriacea, Rutaceae: C. Zanthxylum riedelianum, Sapindaceae: D-H. Serjania lethalis. Smilacaceae: I. Smilax quinquenervia, J. Smilax cf. fluminensis. Verbenaceae: K. Aloysia virgata. (Pictures: Ansaloni, L. S. and Salmazo, J. R.). 
Ansaloni, L.S. et al.

Table 3. Richness of gall morphotypes in plant host family and species in Sorocaba, Southeast of São Paulo State, Brazil.

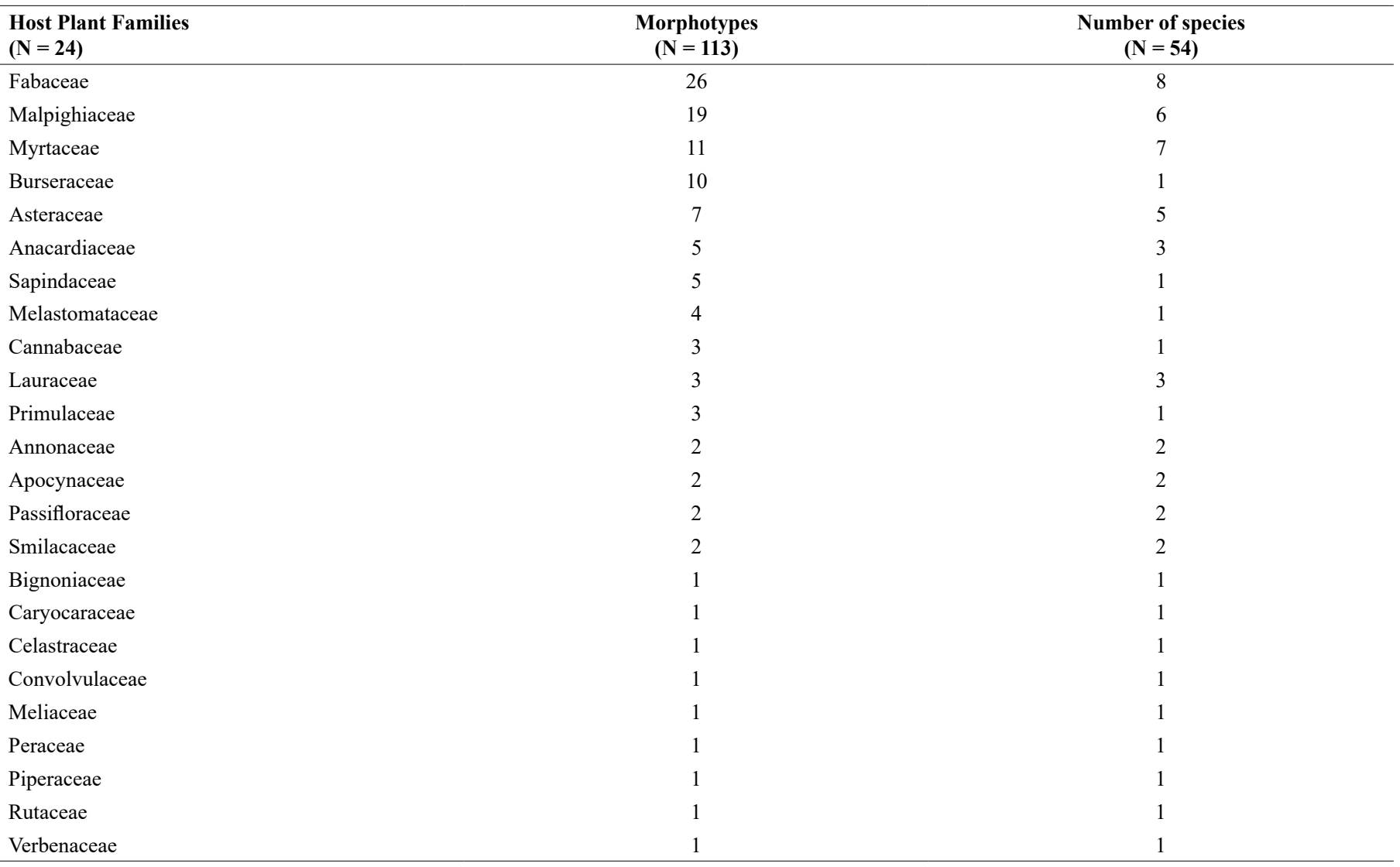

Table 4. Gall makers and associated fauna found in gall morphotypes in host plants from Sorocaba, Southeast of São Paulo State, Brazil.

\begin{tabular}{|c|c|c|c|c|}
\hline Host plant family & Host plant species & Gall maker & Associated fauna & Figure \\
\hline Anacardiaceae & Tapirira guianiensis & Cecidomyiidae & - & $2 \mathrm{D}$ \\
\hline Annonaceae & Duguetia furfuracea & Hymenoptera & - & $2 \mathrm{G}$ \\
\hline Asteraceae & Mikania sp. & - & Hemiptera & $2 \mathrm{M}$ \\
\hline Asteraceae & $\begin{array}{l}\text { Moquiniastrum } \\
\text { polymorphum }\end{array}$ & - & Hymenoptera/Acari & 20 \\
\hline Burseraceae & Protium heptaphyllum & - & Psocoptera & $2 \mathrm{R}$ \\
\hline Burseraceae & Protium heptaphyllum & - & Hemiptera & $2 \mathrm{~T}$ \\
\hline Fabaceae & Bauhinia longifolia & Cecidomyiidae (larva) & Psocoptera & $3 R$ \\
\hline Fabaceae & Callindra foliolosa & Contarinia sp. (Cecidomyiidae) & Hymenoptera & $3 \mathrm{~T}$ \\
\hline Fabaceae & Copaifera langsdorffii & - & $\begin{array}{l}\text { Psocoptera/Hemiptera/Hymenoptera } \\
\text { (Formicidae)/Acari }\end{array}$ & $4 \mathrm{D}$ \\
\hline Melastomataceae & Miconia sp. & Bruggmanniella sp. (Cecidomyiidae) & Thysanoptera/Hemiptera/Hymenoptera & $5 \mathrm{C}$ \\
\hline Myrtaceae & Myrtaceae sp. 1 & - & Psocoptera & - \\
\hline Myrtaceae & Eugenia pluriflora & Cecidomyiinae & Hymenoptera/Acari & $5 \mathrm{~L}$ \\
\hline Myrtaceae & Myrcia splendens & Dasineura sp. (Cecidomyiidae) & Hymenoptera & 50 \\
\hline Primulaceae & Myrsine coriacea & - & Acari & $6 \mathrm{~B}$ \\
\hline Sapindaceae & Serjania lethalis & - & $\begin{array}{l}\text { Trotteria (Cecidomyiidae)/ } \\
\text { Hymenoptera/Acari }\end{array}$ & $6 \mathrm{D}$ \\
\hline Smilacaceae & Smilax quinquenervia & - & Hymenoptera/Acari & $6 \mathrm{I}$ \\
\hline Verbenaceae & Aloysia virgata & Cecidomyiidae & Hemiptera & $6 \mathrm{~K}$ \\
\hline
\end{tabular}




\section{Acknowledgments}

The authors acknowledge Dr. Ingrid Koch (Unicamp), MSc. Ana Carolina Devides Castello (Unesp/Botucatu) and MSc. Ana Laura Scudeler (Unesp/Botucatu) for the identification of botanical species, Dr. Gilberto José de Moraes (Esalq/USP) for the identification of Acari species, and CNPq by scientific initiation grant of Leticia Salvioni Ansaloni (PIBIC/CNPq Proc. \#102480/2015-0) and Julia Rodrigues Salmazo (PIBIC/CNPq Proc. \#101881/2015-0).

\section{Author Contributions}

Leticia Salvioni Ansaloni - Contribution in the: concept of the study; data collection; data analysis and interpretation; manuscript preparation, contribution to critical revision, adding intellectual content.

Julia Rodrigues Salmazo - Contribution in the: data collection; data analysis and interpretation; contribution to critical revision.

Maria Virginia Urso Guimarães - Contribution in the: concept and design of the study; data collection; data analysis and interpretation; manuscript preparation, contribution to critical revision, adding intellectual content.

\section{Conflicts of interest}

The authors declare that they have no conflict of interest related to the publication of this manuscript.

\section{References}

ARAÚJO, W.S. 2011. Can host plant richness be used as a surrogate for galling insect diversity? Tropical Conservation Science 4(4):420-427.

ARAÚJO, W.S., SCARELI-SANTOS, C., GUILHERME, F.A.G. \& CUEVASREYES, P. 2013. Comparing galling insect richness among Neotropical savannas: effects of plant richness, vegetation structure and super-host presence. Biodiversity and Conservation 22(3):1083-1094.

BERGAMINI, B.A.R., BERGAMINI, L.L., SANTOS, B.B. \& ARAÚJO, W.S. 2017. Occurrence and characterization of insect galls in the Floresta Nacional de Silvânia, Brazil. Papéis Avulsos de Zoologia 57(32):413-431.

BREGONCI, J.M., POLYCARPO, P.V., MAIA, V.C. 2010. Insect galls of the Parque Estadual Paulo César Vinha (Guarapari, ES, Brazil). Biota Neotropica 10(1):265-274.

CARNEIRO, M.A.A., BRANCO, C.S.A., BRAGA, C.E.D., ALMADA, E.D., COSTA, M.B.M., MAIA, V.C. \& FERNANDES, G.W. 2009. Are gall midge species (Diptera, Cecidomyiidae) host-plant specialists? Revista Brasileira de Entomologia 53:365-378.

CARVALHO, L.L.G., SANTOS, R.N.S. \& BARBOSA, J.S. 2015. Ocorrência de galhas entomógenas em plantas do Parque Florestal dos Pioneiros, em Maringá, Paraná, Brasil. Revista Uningá 23(1):21-23.

CARVALHO-FERNANDES, S.P., ALMEIDA-CORTEZ, J.S. \& FERREIRA, A.L.N. 2012. Riqueza de galhas entomógenas em áreas antropizadas $\mathrm{e}$ preservadas de Caatinga. Revista Árvore, 36:269-277.

COELHO, M.S., ALMADA, E.D., FERNANDES, G.W., CARNEIRO, M.A.A., SANTOS, R.M. \& SANCHEZ-AZOFEIFA, A. 2009. Gall inducing arthropods from a seasonally dry tropical Forest in Serra do Cipó, Brazil. Revista Brasileira de Entomologia 53(3):404-414.

CORRÊA, L.S., CARDOSO-LEITE, E., CASTELLO, A.C.D., COELHO, S., KORTZ, A.R., VILLELA, F.N.J., KOCH, I. 2014. Estrutura, composição florística e caracterização sucessional em remanescente de Floresta Estacional Semidecidual no Sudeste do Brasil. Revista Árvore 38(5):799-809.
DRUMMOND, M.M., MOREIRA, A.S.F., SOARES, G.L.G. \& ISAIAS, R.M.S. 2008. Potencialidades morfogênicas de Copaifera langsdorffii Desf. (Fabaceae): super-hospedeira de herbívoros galhadores. Revista de Biologia Neotropical 5(1):31-39

FERNANDES, G.W. \& NEGREIROS, D. 2006. A comunidade de insetos galhadores da RPPN Fazenda Bulcão, Aimorés, Minas Gerais, Brasil. Lundiana 7(2):111-120

FERNANDES, G.W., TAMEIRÃO-NETO, E., MARTINS, R.P. 1988. Ocorrência e caracterização de galhas entomógenas na vegetação do campus Pampulha da Universidade Federal de Minas Gerais. Revista Brasileira de Zoologia 5:11-29.

FERNANDES, G.W., ARAÚJO, R.C., ARAÚJO, S.C., LOMBARDI, J.A., PAULA, A.S., LOYOLA-JR, R. \& CORNELISSEN, T.G. 1997. Insect galls from savanna and rocky fields of the Jequitinhonha valley, Minas Gerais, Brazil. Naturalia 22:221-224.

GAGNÉ, R.J. 1994. The Gall Midges of the Neotropical Region. Cornell University Press, Ithaca, New York, p 352.

ISAIAS, R.M.S., CARNEIRO, R.G.S., OLIVEIRA, D.C. \& SANTOS, J.C. 2013. Illustrated and Annotated Checklist of Brazilian Gall Morphotypes. Neotropical Entomology 42:230-239.

JULIÃO, G.R., AMARAL, M.E. \& FERNANDES, G.W. 2002. Galhas de insetos e suas plantas hospedeiras no Pantanal Sul Mato Grossense. Naturalia 27:47-74.

JULIÃO, G.R., VENTICINQUE, E.M., FERNANDES, G.W. 2015. Richness and abundance of gall-forming insects in the Mamirauá Várzea, a flooded Amazonian forest. Revista Uakari 1(1):39-42

MAIA, V.C. 2001. The gall midges (Diptera, Cecidomyiidae) from three restingas of Rio de Janeiro State, Brazil. Revista Brasileira de Zoologia 18(2):583-629.

MAIA, V.C. 2012. Characterization of insect galls, galls makers, and associated fauna of Platô Bacaba (Porto de Trombetas, Pará, Brazil). Biota Neotropica 11(4):1-17.

MAIA, V.C. 2013a. Galhas de insetos em restingas da região sudeste do Brasil com novos registros. Biota Neotropica 13:183-209.

MAIA, V.C. 2013b. Insect galls of São Tomé das Letras (MG, Brazil). Biota Neotropica 13:164-189.

MAIA, V.C. \& CARVALHO-FERNANDES, S.P. 2016. Insect galls of a protected remnant of the Atlantic Forest tableland from Rio de Janeiro State (Brazil) Revista Brasileira de Entomologia 60(1):40-56.

MAIA, V.C. \& FERNANDES, G.W. 2004. Insect galls from Serra de São José (Tiradentes, MG, Brazil). Brazilian Journal of Biology 64(3a):423-445.

MAIA, V.C., MAGENTA, M.A., MARTINS, S.E. 2008. Ocorrência e caracterização de galhas de insetos em áreas de restinga de Bertioga (São Paulo, Brasil). Biota Neotropica 8(1):167-197.

MAIA, V.C., CARDOSO, L.J.T. \& BRAGA, J.M.A. 2014. Insect galls from Atlantic Forest areas of Santa Teresa, Espírito Santo, Brazil: characterization and occurrence. Boletim do MBML 33:47-129.

MALVES, K. \& FRIEIRO-COSTA, F.A. 2012. List of plants with galls induced by insects from the UNILAVRAS/Boqueirão Biological Reserve, Ingaí, State of Minas Gerais, Brazil. Checklist 8(3):426-431.

MARTINS, S.V., SILVA, N.R.S., SOUZA, A.L. \& NETO, J.A.A. 2003. Distribuição de espécies arbóreas em um gradiente topográfico de Floresta Estacional Semidecidual em Viçosa, MG. Scientia Florestalis 64:172-181.

OLIVEIRA, D., DRUMMOND, M.M., MOREIRA, A.S., SOARES, G. \& ISAIAS, R. 2008. Potencialidades morfogênicas de Copaifera langsdorffii Desf. (Fabaceae): Super-hospedeira de herbívoros galhadores. Revista de Biologia Neotropical 5(1):31-39.

RIBEIRO, A.N., BALBI, M.IP.A. \& URSO-GUIMARÃES, M.V. (submitted). Characterization of insect galls from Seasonal Semideciduous Forest and Cerrado area in Altinópolis, São Paulo, Brazil. Papéis Avulsos de Zoologia (submitted to Papéis Avulsos de Zoologia). 
RODRIGUES, A.R., MAIA, V.C., COURI, M.S. 2014. Insect galls of restinga areas of Ilha da Marambaia, Rio de Janeiro, Brazil. Revista Brasileira de Entomologia 58:173-197.

SAITO, V.S., URSO-GUIMARÃES, M.V. 2012. Characterization of galls, insect galls and associated fauna of Ecological Station of Jataí (Luiz Antônio, SP). Biota Neotropica 12:99-107.

SANTANA, A.P. \& ISAIAS, R.M.S. 2014. Galling insects are bioindicators of environmental quality in a Conservation Unit. Acta Botanica Brasilica 28(4):594-608.

SANTOS, B.B., FERREIRA, H.D. \& ARAÚJO, W.S. 2010. Ocorrência e caracterização de galhas entomógenas em uma área de Floresta Estacional Semidecídua em Goiânia, Goiás, Brasil. Acta Botanica Brasilica 24(1):243249.

SANTOS, J.C., ALMEIDA-CORTEZ, J.S., FERNANDES, G.W. 2011. Richness of gall-inducing insects in the tropical dry forest (caatinga) of Pernambuco. Revista Brasileira de Entomologia 55(1):45-54.
SCARELI-SANTOS, C., URSO-GUIMARÃES, M.V\& VARANDA, E.M. 2005. Galhas, Galhadores e Insetos Associados. In: Pivelo V, Varanda EM (eds) O cerrado Pé-de-Gigante: ecologia e conservação: Parque Estadual de Vassununga. Secretaria do Meio Ambiente do Estado de São Paulo, São Paulo, pp 223-246.

URSO-GUIMARÃES, M.V. \& SCARELI-SANTOS, C. 2006. Galls and Gall makers in plants from the Pé-de-Gigante Cerrado Reserve, Santa Rita do Passa Quatro, SP, Brazil. Brazilian Journal of Biology 66(1b):357-369.

URSO-GUIMARÃES, M.V., SCARELI-SANTOS, C., BONIFÁCIO-SILVA, A.C. 2003. Occurrrence and characterization of entomogen galls in plants from natural vegetation areas in Delfinópolis, MG, Brazil. Brazilian Journal of Biology 63(4): 705-715.

URSO-GUIMARÃES, M.V., CASTELO, A.C.D., KATAOKA, E. \& KOCH, I. 2017. Characterization of entomogen galls from Mato Grosso do Sul, Brazil. Revista Brasileira de Entomologia 61(1):25-42.

VELDTMAN, R. \& MCGEOCH, M.A. 2003. Gall-forming insect species richness along a non-scleromorphic vegetation rainfall gradient in South Africa: the importance of plant community composition. Austral Ecology, 28:1-13. 